\title{
Terror as Potentiality - the Affective Rhythms of the Political
}

\author{
Dolendi modus, timendi non item. \\ (Pain has a limit; fear has none.) \\ Francis Bacon
}

In the primordial scene, which Girard (1986) describes, the society is constituted on the basis of the lynching mob, whose mimetic desire, whose envy and egoism, culminates in sacrificing the scapegoat. Likewise, Serres (2015) shows that violence and murder are constitutive of sociality. With terror, though, we confront the opposite situation in which the mimetic desire and murder do not establish but rather destroy the 'society.' Importantly, the spatio-temporal process at which self-destruction and destruction merge is also a process that produces fear. In this particular sense, terror is productive despite its spatial destruction and radical detemporalization. Indeed, with the becoming rule of exception, with the move from 9/11 to the politics of security, terror (and the war against terror) has today already become a factor of sociality, which sustains, rather than shatters, the business as usual. Terror is no longer merely an exceptional (real or imagined) catastrophe but has become a dispositif, a technique of governance which imposes a particular conduct, a new model of truth and normality, on contemporary sociality by redefining power relations and by unmaking previous realities.

We start, against this background, with explicating the significance of fear as a political instrument, relating this to terror. What is crucial in this respect is the virtual dimension of terror, its potentiality, which is not reducible to an actual spatial setting or a linear chronology (see Shields 2002: 211-2). Then we turn to Kierkegaard to distinguish fear and anxiety. We associate this distinction with the notion of securitization as the dominant political response which terror attacks initiate. Next, we focus on how the threat of terror and the fear it provokes affect the spectator. This is followed by the discussion of a key aspect of anxiety, its decisive relation to an amorphous object. We examine this formlessness by focusing on the anatomy of terror. Then we turn to the question of how one can relate to terror in terms of reason. We outline and differentiate between three approaches to the threat of terror in terms of rationality, foolhardiness and paranoia. The problem with this exercise, however, is that terror, as a radical catastrophe that per definition transgresses given spatio-temporal boundaries cannot really be domesticated. There is no rational way to deal with catastrophes. Why this is the case is the theme of our concluding discussion where we elaborate on ethical-moral aporias engendered by terror. Finally, we juxtapose the monstrousness of terror and a sense of politics as demonstration.

Fear 
The political significance of fear is as old an issue as the question of the political itself. Machiavelli, to recall, advises the prince that it is 'much safer to be feared than loved' (1999: 79). People have one primary concern, the fear of losing their lives, and they would always follow a strong leader if there is someone they fear more. ${ }^{1}$ However, it is first Hobbes who articulated the nexus of fear, security and political order. While for Machiavelli this nexus was basically a matter of observation and advice to the Prince, Hobbes turned it into the very starting point of political thought. Thus in Leviathan (1996), named after one of the two mythical monsters in the Old Testament, he describes the emergence of the state on the basis of an imaginary contract. In a distant past, individuals had lived in a natural state, without a state power. There existed no police and no military, no instance to take care of one's security; everybody was a potential enemy, life was 'solitary, poor, raw, brutal and short' (Hobbes 1996: 89). Thus individuals realized that it was better to transfer their natural right to use force to a sovereign, an event which marks the foundation of the modern state.

Yet, the state of nature was not so remote a fiction, as Hobbes' argument could lead one to believe. The English civil war in the mid- $17^{\text {th }}$ century had ravaged the cities and the countryside, claiming almost 200,000 victims (Robin 2004: 33). Hobbes describes this war in Behemoth (1990), a title chosen as a reference to the other monster in the Old Testament. Only a monster can fight a monster. Like Machiavelli's, Hobbes' state was a powerful authoritarian state that inspired fear in its citizens. But it was far more tolerable than the world it was designed to fight. As with Machiavelli, the fear of death led man to accepting an authoritarian regime. The fear of the formless and unpredictable, of enemies who could attack at any time, was replaced by the fear of the state. Fear, in other words, was put in the service of politics.

Such a digression might seem unnecessary, but it is far from it. The fear of terror today is precisely the fear of a natural state where, in the absence of effective security assurances, people would be left to their own to defend themselves. Terror can have many reasons. One key aim is to humiliate the state, to show that it is unable to defend its citizens. Terror is fundamentally a violation of the state's monopoly of violence. But its most important outcome is always fear. One could here distinguish between 'old' and 'new' terror (Neuman 2009). Certainly, there are many problems with this distinction (Duyvesteyn 2010), but it helps to discern a movement from one kind of ('old') terror, which was mainly directed against political opponents and representatives of the state apparatus with limited damage to follow, to another kind, the 'new' terror, which hits blindly in order to create maximum damage as everybody becomes a potential target. We had seen such catastrophic terrorism before (like the bombing of Bologna train station in 1980), but 9/11 signifies the becoming rule of exception in this respect. With the 'new' terror, the fear of the populations - the culture of fear-tends to become a general and urgent problematic. This kind of terror, precisely, realizes the idea of terror, that is, fear.

Not everything, obviously, is explained by relating terror to fear, but quite a lot starts to make sense. Terror is mentioned already in the Bible, associated with the trembling instigated by the wrath of God. Only later this trembling was connected to something specifically political. What is dragged with is the fear of the unexpected and the sensation of being totally exposed to a power one cannot match. As such, terror is irrational and incomprehensible. But there is also a substantial displacement. Divine anger hits people like a thunderbolt from a clear sky. You tremble. Today's terror, however, works not only on its immediate victims. Equally central to

\footnotetext{
${ }^{1}$ Immediately after 9/11, for instance, Bush's popularity grew exponentially as a 'war president.' With later terror attacks in different settings, the same pattern reappeared. When hit by terror, the issue of security turns into the fundamental concern of politics.
} 
it is a desire to affect the audience. A terrorist attack opens up a horizon, in which the imagination of the spectator is set into motion. And this secondary effect can be more significant and more devastating than the primary. Here the fear revolves around potentialities reminiscent of the aftershocks that might follow an earthquake. Terror initiates after-effects, opening up the space for a culture of fear.

\section{Anxiety and fear}

As with Machiavelli, in Hobbes it is the formless, unfocused fear that causes anxiety. The question here is whether we should not make a distinction between two kinds of fear, the focused and unfocused. Following Kierkegaard (1981), fear has a given object. One always fears something. Anxiety, on the other hand, is an existential condition, an undetermined fear of 'nothing.' Canetti writes: 'There is nothing that man fears more than the touch of the unknown. He wants to see what is reaching towards him, and to be able to recognize or at least classify it' (1962:15). To make visible the object of anxiety, to know what threatens, is to transform anxiety into fear, which brings with relief. This process can also be traced at a social level, if we relate the distinction between fear and anxiety to the politics of security. Crucially in this respect, security is a contested issue. While some actors may insist that a given problem relates to security and thus requires extraordinary measures, others might see it differently and claim that the problem can be handled through normal political processes (see Waever 1997: 211-256). Actors can in this way fight to securitize or de-securitize a particular problem, that is, move it from the agenda of normal politics to that of the politics of security or the other way around. What is of particular interest in our context is that securitization has psychological and socio-psychological consequences. To securitize, to designate something as a threat to existence, evokes fear. The ultimate fear is the fear of losing one's life or livelihood, and the politics of security thematizes such a situation.

Securitization contains several elements, the most important of which is declaring a given object - a population, an economy, the eco-system, an identity or something completely different - to be existentially threatening (Buzan et al. 1998: 21ff). This object is perceived to claim to persist no matter what, which implies the necessity of immediate and extraordinary defense measures. Hence securitization often calls for a state of emergency. It is important to emphasize in this respect that the dominant governmental paradigm today is neither democratic nor political (Agamben 2013). In spatial and temporal terms, the politics of security has its origin in the state of exception, which is, per definition, limited in space and time. In this period and within this space it is as if the statue of liberty has been veiled (Agamben 1998: 57). Today, however, we live under a 'fictitious emergency,' which is not formally declared but instead refers to non-juridical, security-related, non-determinate dangers (Agamben 2013). This fictitious state of exception does not target solving problems; rather, it lets them happen, seeking to manage their effects. Hence 'the paradoxical convergence today of an absolutely liberal paradigm in economy with an unprecedented and equally absolute paradigm of state and police control' (Ibid.). In this sense, the politics of security seeks to deal with the effects of terror rather than its causes. However, as effects are sought to be controlled and governed while the causes recede to the background, anxiety increases and security becomes an increasingly significant concern outweighing democratic participation, a situation, in which the citizens fear not the security state but its absence. The appeal to security is a gesture of withdrawal of certain questions from the political agenda. Thus the politics of security is not merely a 'continuation of politics by other means'; rather, it overrides politics. The aspiration to 'protect freedoms' is 
pushed to the margins by the logic of a victory or defeat, which will protect 'us' against the anxiety-provoking others. ${ }^{2}$

What is crucial in this context is that security necessarily creates its twin: insecurity. To securitize an issue is also to create a danger. In this way, by constructing an existential threat, the politics of security provokes fear. Nevertheless, security can also be seen as a calming or pacifying action that transforms an indefinable anxiety into something concrete which we can fear. The politics of security thus appeals, with its rhetoric of threat, to the feeling of insecurity, but at the same time it transforms the diffuse anxiety, which it itself constructs, into a more tangible and manageable fear, insofar as such a response appears desirable and convincing. ${ }^{3}$

At this point, in order to relate the distinction between anxiety and fear to the theory of securitization, we can distinguish between three different ways to effectively securitize a given topic. The first scenario is that a situation can be securitized without designating a concrete threat. There was a tendency for this kind of securitization when the 'war on terror' was first launched; this war was so vague that it was impossible to win. The second scenario is that a situation is securitized, a concrete threat is designated, but without a realistic response being offered or considered as possible. We know who will kill and how, but we do not have an adequate defense. Such a situation will provoke a crippling fear and will be avoided at all costs. Finally, a state can securitize a specified threat and take the necessary precautions. Such action induces fear, but what is feared is combated effectively. If one takes as a starting point such a distinction between insecurity and security, and securitization as a movement from the one to the other, it will not seem surprising that the US and later Europe chose to act as they did.

To illuminate what is problematic in this response, we must recall a central problem in Machiavelli and Hobbes. The fear of the enemy leads us to accept a form of government and political and military action, which is anything but democratic. Machiavelli and Hobbes' state is a state which has security as its raison d'etre. They tend to overlook the fact that the state is not always and not necessarily threatened on its own security. Securitization can be a political strategy. Machiavelli and Hobbes can only think of two scenarios: that one is safe (the threat is met by securitization and appropriate counter-measures) or unsafe (the threat is there but the response is not credible). As such, their state functions as a state in a constant state of exception. But isn't there a normal state, where threats are not imminent, and where the need or desire for powerful and autocratic leaders do not arise?

To discuss this, it is not enough to distinguish between security and insecurity; we must also focus on a-security, a situation where a given problem is not thematized within the register of the politics of security. It is not at all certain what should be included within this register. Such

\footnotetext{
${ }^{2}$ Consider, for instance, the wall promised to be built on the Mexican border by Trump. The policy illustrates the greatest danger with Trump, the reduction of politics to passion, to fear. And in this, the cultural imagery of populism plays a significant role. But with Trump we seem to be confronted with a new, post-political version of populism. Insofar as post-politics signifies the foreclosure of politics by eliminating real dispute, by assuming that problems can be dealt with through expert systems, Trump would seem to be a reaction against post-politics. Yet, he is post-political in another way. Society is for Trump an oikos, a private business or household. Herein, in this cultural imaginary, the politics of security coincides with the tendency of 'economization,' which, as Foucault (2008) showed, defines the history of West since the $17^{\text {th }}$ century.

3 9/11, for example, was first inexplicable and therefore a source of anxiety. The countermove by the US government was to try to convert this anxiety into fear. Immediately after the attacks there was not much talk of 'home grown terrorism' or of the fact that waging war against a state would hardly eradicate an international, hybrid terrorist network. The threats were supposed to come from outside, and it seemed that they could be determined and combated, even in conventional ways.
} 
decision is based on a political choice. Thus the word 'terror' often serves to securitize a given situation, arguing that normal procedures should be suspended. Consequently, more and more acts are discussed as terrorist acts today. ${ }^{4}$ But what affect corresponds to an a-securitized situation? The excitement, which fear and anxiety are associated with, disappears when politics becomes politics as usual, trivial and everyday-like. Fear is replaced with an absence of fear, even boredom. After all, fear and anxiety cannot be tolerated in the long run. When the afterattack ceases to come, potential catastrophe, the worst case scenario, gradually turns into a matter of sheer probability.

\section{Fear and its social psychology}

Now let us go further and ask why fear is felt, how it is felt, and finally how it can constitute communities or at least have a social dimension. We must explain two movements here, first from anxiety to fear and then from fear to boredom. As already argued, fear is easier to live with than the diffuse anxiety, and despite all its tediousness boredom may be preferable to a life in fear. This latter movement brings with a form of relaxation. But there is also a movement in the opposite direction. 'Successful' terror attacks, for instance, fall in this category. However, in order to understand these two axes of movement, we must reach a deeper understanding of what fear is.

Fear is not an unusual and unnatural feeling. It is to a greater or lesser extent with us all the time. We are, it seems, born with the ability to fear. But that does not mean that we fear that which is rational to fear. Children, for instance, must be taught what to fear. Yet, this fear is of a different kind than the one we have focused on so far. It is a fear, which gradually becomes a matter of routine and therefore functions as a kind of practical consciousness. In contrast, terror attacks attempt, precisely, at destroying routines. Coming as a sudden shock, they thus evoke another kind of fear.

Nevertheless, one can imagine that terror attacks (or threats) become routinized. A remarkable illustration of this is found in Gilliam's (1985) film Brazil, which depicts terrorist attacks as part of daily, monotonous humdrum. The state of exception has become a norm, and people have adapted themselves to it. In one scene, the film's protagonists are dining in a restaurant, suddenly a bomb goes off, and the victims are scattered all over the restaurant. The waiters bring a folding screen around our protagonists who eat on as if nothing had happened. Yet, only few people have such an ability to live in a normalized state of exception. Our immediate response to exceptional incidents is shock, a condition in which fear comes instinctively and immediately. The bodily reaction usually comes before we reflect upon what has happened. The heart rate increases, adrenaline pumps, one turns red in the head, and in extreme cases, one completely loses control of one's body. First afterwards, and slowly, one begins to understand what has happened, an experience that often leaves a long trace. Fear is corporeal.

In this regard, the relationship between (un)certainty, (in)security and (un)safety is crucial (see Bauman 1999: 5). The politics of security condenses the insecurity, uncertainty and unsafety caused by terrorism to the latter element, the bodily safety, bypassing the burden of looking for political solutions to political problems (insecurity and uncertainty caused by the neo-liberal globalization). This reduction builds upon an image of the society or the city as an entrenched

\footnotetext{
${ }^{4}$ In the 1960s and 1970s, for instance, it was seldom to hear plane hijacking was nominated as terror. Today it is rather the rule than an exception (Stampnitzsky 13).
} 
oikos. Hence the increasing demands for a temporary or even permanent stop to immigration, more border control, and so on.

But why do we fear some things more than others, especially when they are, objectively speaking, less dangerous (mice, spiders...)? In such cases we do not get far with the explanation that we fear that which threatens our life. There is something about the character of the feared object, which determines how much it is feared. Let us here present a new triad of concepts, all of which relate to the type of the threat. The more formless a threat is, the more afraid we are of it. And the threat may be formless in three different ways.

Firstly, the threat can be de-materialized. What threatens us can mutate. And the more the threat changes its form, the more afraid we are of it. Recall the enemy in the first Alien movie. What makes it frightening is that it is both mobile and mutable and can, if necessary, inhabit other bodies. This explains why viral/biological terror is more frightening than anything else. It threatens to contaminate and turn the body into its carrier, making it difficult to distinguish between those who are spreading the disease/terror and those who are fighting it. In such a situation friends and foes cannot be separated, which is, again, anxiety-provoking. What is scary with terror is its ability to simulate and dissimulate. The terrorist is not like a normal soldier wearing a sign of his hostility. With terror, the enemy is potentially unclear and the battlefield is without demarcations; terror is a 'formless war' (Lotringer \& Virilio 1997: 173).

Secondly, de-temporalization increases fear. Daily life is grounded in processes and routines, each with their own temporality. War, too, has its own temporality; it is declared and terminated. Terror demolishes these temporalities, breaking with the distinction between war and peace. Terror is an element of war in a period of peace characterized by routines. Even though it has its own sequences (e.g. the relative regular time intervals with respect to the release of hostages), terror leads to the suspension of everyday life.

Thirdly, the more de-territorialized the threat is, the more fear and anxiety it produces. Social life is subject to a number of geographical distinctions between private and public spaces, between different organizations, and between the national and the international. The circular stratification of such zones suggests that the enemy is one who resides 'outside', and by extension that what is 'inside' (home, nation...) is safe. But what terror really attacks is the notion of a safe zone, its very possibility. To refer to Alien once more: what causes anxiety and fear is the very presence of the monster on board, not its existence as such. The power of terror is to transform 'paradise' into 'hell'.

The more de-materialized, de-temporalized and de-territorialized a threat is, the more uncertainty it induces. We argued earlier that fear has an object while anxiety is a quaking over for 'nothing'. This distinction can be related to our three types of formlessness. If we see the distinction between fear and anxiety as a continuum rather than as a binary distinction, so we will get closer to anxiety, the more formless the threat is. And conversely, we will come closer to fear, the more specific and recognizable it is.

Let us now move from the object of fear to its subject. How does the experience of fear and anxiety, respectively, affect our ability to form communities? Fear facilitates qua its directedness towards an object specific subject positions. When a common enemy is found and fought, a given group's internal tensions could be relaxed by projecting negativity onto this enemy. Hatred of the enemy can, precisely, be shared. Fear thus creates a self and a social bond. The fear disappears, so to speak, in the manner of a vanishing mediator, because it is shared and transformed into other affects such as courage and determination. But with anxiety it is different. It cannot be shared, it does not lead to joint action, and it destroys the self rather 
than empowering it. We can illustrate it by turning to Alien for the last time. Two persons symbolize in the film two different socialities grounded in fear and in anxiety. The film's main character Ripley tries to fight the monster, while Lambert, the navigator, is paralyzed with respect to taking any action. This becomes obvious when it is proposed that they must escape from the ship by using the rescue capsule. The problem is that there is only room for four in the capsule, and there are five left. Lambert proposes that they then must draw lots as to who should have the seats. Ripley reacts against the discord, which the proposal creates, and stresses that they must fight the monster together. Again, anxiety must be focused, turned into fear. For anxiety takes one nowhere; it shatters everything into pieces, not least the social bond.

\section{The substance of terror}

One can fear many things subjectively, everything from spiders to high altitudes or public gatherings. Fear, however, has an objective aspect to it as well. This brings us to the anatomy of terrorism. If we look at the series of terror attacks in the last two decades, their only common denominator seems to be that they have been referred to as terror attacks. There have been discussions of attacks carried out by lone wolves, by terrorist cells and by the Islamic State or the Taliban. Some attacks have been themed as a mad man's work, others as religiously motivated, even as the quintessence of a religious cosmology. Every new attack appears to have ushered in a new kind of terror: pop-jihadism, simple terror, spontaneous terror or, for instance, idiosyncratic terror. And experts stand in line to respond to why terror takes place in a specific country and is performed by a specific group; just to find out that the next terrorist attack hits in another country and has a different background. Can we say anything about the idea and the substance of terror, for instance in the manner of Weberian ideal types, of theoretical figures through which a given logic, a rationale or an organizational characteristic emerges in its purest form and thus can serve as a heuristic hermeneutical tool? Let us try this in relation to terror as a strategy by contrasting it to war (see Laustsen 2014: 27ff).

War demands symmetry: two armies confront each other (but of varying strength, of course), the battle is therefore between soldiers, they wage war in a specific place, on a battlefield, and war is declared and terminated through a treaty. Being asymmetrical, terror is the opposite of war. It breaks down the distinction between peacetime and war, it makes no distinction between soldiers and civilians, and it seeks to avoid any direct confrontation with an enemy, usually by attacking where it is least expected: on a beach, a hotel, a stadium, a church, a grocery store. Thus it can be compared to playing whist. For the terrorist it is all about determining the trump card. If he plays on our ground, if he confronts us in open war and on a battlefield, which we have defined, then he loses. He must be able to avoid the rules and manage to make new ones. This is visible in relation to terrorists' choice of weapons. Terror is idiosyncratic because of its inventiveness, its ability to turn everyday objects into weapons. It can turn a passenger plane into a missile, a car into a bomb. There is not, in principle, anything that cannot be turned into a weapon, and the ultimate weapon in this context is the body. While the soldier puts his life at stake the terrorist plays with it. ${ }^{5}$

\footnotetext{
${ }^{5}$ It is very interesting in this respect that previous forms of terrorism reminded of war (the Russian anarchists of the $19^{\text {th }}$ Century, or organizations such as Beider Meinhoff or RAF in the $20^{\text {th }}$ ) and did almost everything in order to avoid unnecessary 'civilian' victims. Some of them (such as the Red Army faction and Brigato Rosso) perceived themselves as military units (as the terms 'army' and 'brigade' suggest).
} 
The logic of war is basically about avoiding confrontation. Deterrence, that is, the threat of war, and surrender, if the war could not be avoided, are more desirable than the war itself. The best war is the one with fewest casualties. Catastrophe, on the other hand, is terror's trademark. It is through the maximization of catastrophe that terror radicalizes its idea and its substance. ${ }^{6}$ Hence the typical reaction to terror attacks is anxiety. The key here is that terror always points beyond a particular attack. The reality of terror is its possibility, its potentiality. What if...? Apropos of Kierkegaard's definition of anxiety, terror affects not only the direct victims but also the spectators. The bloodier it is, and the more randomly it hits, the more the spectators can identify with the victims and, more importantly, the more their imaginations gain momentum. The substance of terror is the formless.

\section{Cultures of fear and anxiety}

Let us now relate the two sides, the subjective and the objective, to each other. What is the appropriate amount of fear? When is fear rational? As a mental exercise that can bring us on the trail of a response, we can imagine that there is an objectively given threat level and consequently a rational and appropriate response from a given subject/country. We can further assume that some contexts are objectively more threatened than others. If we in this light cross the two dimensions - the objective degree of security and the subjective, perceived level of security - we end up with four possible outcomes, of which two are rational and two irrational. If you are in an unsafe environment, so it is reasonable to feel a high level of fear and, therefore, be very careful. Conversely, if there is no imminent threat, only a small degree of fear will be rational. Then two non-rational positions will be the paranoid position, which pertains to the subject who sees dangers everywhere, and the foolhardy position, of those who have thrown all caution.

However, such reflections only bring us a piece in the direction of a convincing response for the time between the attacks also 'costs' something. The risk of an attack affects everybody in varying degrees and not everybody can live with threats and risks equally well. Some hardly think about risks, while others are obsessed with it. An appropriate emergency response will thus have to be different for different groups. Here we can distinguish three basic ways to relate to things that can go wrong: as accident, as risk or as catastrophe.

First, one can relate to terror as an accident, as something which goes wrong, but which could be avoided and with the right effort will be avoided in the future (Beck 1997:121). Workrelated accidents can, for instance, be minimized through greater focus on safety at work. Many, both on the Left and on the Right, have argued that terror is a kind of accident in a similar way. If we are to do something efficient about terror, we need to better the conditions which create the breeding ground for the extreme anger towards the West, we must to a greater extent respect foreign cultures and so on. But it is often forgotten that al-Qaeda and other groups have a number of political motives and demands (for example that the US must move out of Saudi Arabia, that Israel must vacate the occupied territories, and so on). It is the standard 'Left-wing' solution to listen to these demands in order to deal with the subject of terrorism. Another option, the standard 'Right-wing' solution, is to build up one's defenses so heavily

\footnotetext{
${ }^{6}$ But catastrophe here is not merely about the number of victims. Catastrophe is essentially the ambition of a radical upheaval of a given order. From the viewpoint of the terrorist, terror is about a radically different political or social order. This is why terrorism is punished harder than other conventional crimes. The ordinary criminal carries out his deed knowing that he transgresses the law. Hence he seeks anonymity. The terrorist, in contrast, holds his demands publicly and looks for recognition for the righteous in his case.
} 
that terror becomes impossible, or at least is reduced to occur rarely. You may get far with these two strategies, but to think that one can invest or fight one's way out of terror is a problematic idea in itself. One of the most obvious problems in this regard is that policy interventions in other countries, regardless of the intentions that back them, often give rise to greater resentment and anger. If you send drones after a suspected terrorist but instead hit a wedding, you help to accumulate an increased hatred, which will be reflected in a later cycle of terror. There is in this sense always a boomerang effect in wait as a consequence of the ambition to eliminate the 'bads' (Beck 2002a, 2002b; Diken \& Laustsen 2004: 27ff).

Second, one can relate to terrorism as a risk, as an inevitable problem, which cannot be fully fought away through diplomacy or military invention. Terror is something we have to live with in the same way as we have to live with traffic accidents if we want private cars. If one accepts that there will always be terror, one can seek to calculate terror as a risk and insure against it. After all, such a risk calculation followed by financial compensation is the way we meet most other dangers on, why not also terror? Should we necessarily accept that terror is something special?

Finally, one can relate to terror as a catastrophe, as a radical shock, which never must happen. Not a single catastrophe can be accepted. Consequently, one must act preventively. The starting point here is zero tolerance. Relating to terror as a catastrophe is an obvious choice also because it is the way in which the terrorists want us to perceive it. The problem here, though, is that it is difficult, if not impossible, to relate to the monstrous and radically unexpected effectively in a preventive way. Thinking terror in terms of catastrophe leads to an alarmism which is of little practical use.

One might think that the middle version is the optimal, neither overly optimistic nor pessimistic. What can be more rational than a predictive calculus? It is not quite so easy, however, for the essence of terrorism is precisely to break with any calculus. Besides, the degree of risk aversion or catastrophe-consciousness is variable. We can in relation to the latter return to our three mental states. To a society that perceives terror as accident corresponds the mental state which we called boredom: a political culture, which assumes that there is a reasonable solution to every problem. There may be incidences here and there, but in the long run everything will fix itself. A society that confronts its problems as risk is one where people feel fear. Such a society assumes that there is a possible response for every threat. It is not possible to prevent things from going wrong, or remove the threat completely, but we have a response, whether this is an insurance policy or a security initiative. Finally, a focus on catastrophes is followed by an experience of anxiety. The catastrophe is precisely the indefinite threat which one cannot put in words or conceptualize, which is why it evokes anxiety.

Beck (1997) has argued that we have moved from a society that focuses on accidents to one that focuses on risks. The first modernity was characterized by a blind faith in technology; the second modernity, or 'risk society', by the fact that we know that any technological innovation can create new problems. Beck mentions in this context the nuclear catastrophe in Chernobyl in 1986 as a succinct example of modernity's inherent risks. But he blends here two very different rationales together. To relate to something as a risk is precisely to standardize it according to a calculus, while catastrophe is that which destroys a given calculus. One could also ask, along the same lines, whether we currently live in a society of fear (corresponding to a focus on risks) or in a society of anxiety (corresponding to a focus on catastrophes). But this question is wrongly posed. The three ways to deal with terror (and other things that can go wrong) are three ways to comprehend terrorism. It is not a question of three social formations replacing one another in succession, but of three potentially coexisting rationales. Often, 
however, a rationale would dominate the others (just as 'catastrophe' was the dominant form immediately after 9/11 and accident and risk paradigms seem to be dominant today).

However, it is not the case that we have left for good the 'society of fear' and now inhabit the 'society of anxiety' or the 'society of catastrophe.' What is interesting in this respect is to observe the movements between these three discourses and the corresponding mental states. How we will deal with terrorism is a political choice. By the same token, the right response is not to dictate. No matter what, we are handed over to choose how we will live with terror.

\section{The aporias of catastrophe thinking}

When we relate to terror it is, of course, the issue of catastrophe, which comes to the forefront. Terror comes in many forms, but the essence of the attacks in the US, Europe and the Middle East in the last decades was to show that nothing was for the terrorists impossible and therefore that the next attack could be even worse. But this way of thinking is also a sure sign of losing. A system that thinks along these lines collapses in the same way as anxiety devours those who suffer from it. This way of thinking ends up, paradoxically, in an absence of thinking, in an intellectual meltdown. Thus, by way of conclusion, we want to point out four aporias, four structures of impossibility, embodied in catastrophe thinking.

The radical catastrophe is not only given by its scope, but also by being an event that bursts our categories. Terror as catastrophe signifies what is radically unexpected and unimaginable, and there are no adequate security measures against catastrophes. Our knowledge and capability will always be inadequate in relation to terror. The unimaginable cannot be imagined. The formless can be given a form, but so one transforms it into something else. The second aporia refers to the war against terror. If one took every possible step to counter terror, one would only create a terrorist state. In the twentieth century almost 200 million people were killed through state terror, primarily aimed against its own populations. In the twenty first century state terror is called the politics of security, which justifies itself with reference to and thus mirrors terror. Thus it can curb citizenship rights to save democracy, kill people to protect them from despots, and legalize torture to preserve human dignity.

The thought of security bears within it an essential risk. A state which has security as its sole task and source of legitimacy is a fragile organism; it can always be provoked by terrorism to become itself terroristic. (Agamben 2001)

When the difference between terror and state disappears, they start to justify each other, terrorizing the political itself. The obscene/off-scene reality behind the politics of security is that 'security' brings with it more terror. Obsession with security, that is, living in permanent anxiety and fear, is the real victory of terrorism (Baudrillard 2003: 81).

\footnotetext{
The state in which we live now, in the 'war on terror', is one of the endlessly suspended terrorist threat: the Catastrophe (the new terrorist attack) is taken for granted, yet endlessly postponed. Whatever will actually happen, even if it will be a much more horrible attack than that of 9.11, will not yet be 'that'. And it is crucial here that we accomplish the 'transcendental' turn: the true catastrophe is already this, life under the shadow of the permanent threat of a catastrophe. (Žižek 2003: 143)
}

The ultimate catastrophe, emerging from the war against terror, is the disappearance of politics. In a sense, therefore, it is deceptive to speak of a 'politics' of security for the difference between 'normal' politics and politics of security is not a quantitative but a qualitative difference. The difference is between politics as such and a politics that consciously rejects the political nature of given questions. The antagonism is thus not between those who say the world today is secure 
and those who say it is not. Rather, the antagonism is between those who would consider it a problem within the horizon of politics of security and those who would not. In other words, the antagonism is between security and a-security, not between security and insecurity (Wæver 1997). Politics of security is, above all, about finding apolitical solutions to political problems. War, said Clausewitz, is the continuation of politics with other means; the war against terror, or the politics of security, is the continuation of trans-politics or post-politics (or the lack of politics) with other means. If the desire to respond to the catastrophe, terror, may itself evolve into the ultimate catastrophe with or without our reckoning, if life in the shadow of terror can be more excruciating than terror itself, the aporia we have here has the structure of a moebius strip. The farther one moves on the strip, the closer one comes to a reverse position.

The third aporia is that it is impossible to determine what an appropriate level of preparedness consists in regarding possible catastrophes. Is the fact that for a time there has not been any terrorist attacks, for instance, an argument for that the level of preparedness is exaggerated or appropriate? If the catastrophe is the unexpected, a catalogue of attacks which are successfully fended off cannot be a guide. In relation to terror one must, exactly, act in relation to the unexpected, must, paradoxically, prepare for it. We see the same problem in many different forms, for example in relation to the so-called de-radicalization attempts. How can one prove that a potential terrorist, who is exposed to anti-radicalization measures, would have blown himself up if these measures were not implemented? Or, how can one prove that one doesn't want to blow oneself up in a number of years? To combat potential threats before they are actualized, of course, is possible, but to decide on what those potential threats are is immediately more difficult, indeed logically impossible to determine with certainty.

The fourth aporia is that the catastrophe ceases to be a catastrophe as soon as one deals with it and acknowledges its character. The unexpected becomes something expected and explained. The prevented catastrophe is no longer a catastrophe, but precisely something that can be prevented, a potential accident. When we intervene into terror, it is always with a backward glance; hence one often hears that 'we ought to be able to see it coming'. But terror is an unbound act of will; like evil, radical and unexplained. Terror and catastrophes can thus be seen as radical evil (un-decidable, unexplained, a shock, a suspension of our everyday rhythms) on the one hand, and as conditioned on the other. But something cannot be both radically new and conditioned at the same time.

The new terror forces us to think in terms of catastrophe scenarios. As such, it evokes an unbearable anxiety. But anxiety eats our souls up as well, so for that reason alone should any attempt to deal with the threat of terror at any scale smaller than 'catastrophic' would be welcome. The desired effect of terror is to create a state of anxiety. Terror evokes anxiety, but with time we get a distance to it, anxiety gradually fades away, and we return to the rhythm of everyday life. This is the standard reaction to 'foreground catastrophes' (Žižek 2003). Suddenly something catastrophic happens, which shatters the frame of the normal. But it is precisely a normality, which we can return to. Yet, terror can itself become a norm, a daily phenomenon, that is, a 'a background catastrophe' (Ibid.) and it does so for those who are caught up in the limbo between terror and the war against terror. Indeed, without relativizing terror attacks on American and European soil, it can be asserted that the reality in Syria and Iraq today is a different one. So we not only have to stop talking about terror as the ultimate catastrophe and try to act accordingly. ${ }^{7}$

\footnotetext{
7 There is also an ethical problem here: the preoccupation with our own anxiety seems out of place and skewed in comparison to those who live not with the threat of terror but terror itself as part of their daily lives.
} 
What is immediately necessary in the face of a formless, monstrous terror, in the face of monstrousness of anxiety, however, is a politics of de-monstration. The monstrous cannot be demonstrated; its monstrousness is grounded in its very formlessness. But one can give form to a dissensus in relation to the false antagonism between terror and the politics of security that feed upon each other in a monstrous pact. For politics involves seeing, staging and demonstrating things differently, on the basis of disagreement, which is, above all, a disagreement on consensus. 'Consensus', however, is not only the avoidance of conflict. At a deeper level, it is an agreement regarding the terms of disagreement (Rancière 2010: 144). That is, it allows one to have different opinions, to disagree, criticize, even to engage in an 'antagonistic' war, but only in a given framework of sensibility, which is effectively justified each time permitted disagreements take place. Such is the 'antagonism' between terror and securitization. The true target of dissensual politics, in turn, is this framework itself; not playing a given game, indulging in its permitted transgressions, but utterly changing the game itself. Politics in this sense is a process of separation, of dis-identification, vis-à-vis a given framework of the sensible. To politicize is to juxtapose sense to sense, to contrast another sensibility to the given distribution of the sensible (Ibid., 212). To open up a space for what can be said, seen and thought otherwise, to intervene in the flow of time in order to change its course and its rhythm.

\section{References}

Agamben, G. (1998). Homo Sacer. Sovereign Power and Bare Life. Stanford: Stanford University Press.

Agamben, G (2001) “Heimliche Komplizen. Über Sicherheit und Terrer”. Frankfurter Allgemeine Zeitung, No 219, 20. September, p. 45.

Agamben, G (2013) 'For a theory of destituent power,' Public lecture, Nicos Poulantzas Institute, Athens, 16.11.2013, available at: http://criticallegalthinking.com/2014/02/05/theory-destituent-power/

Baudrillard, J (2003) The Spirit of Terrorism. London: Verso, $2^{\text {nd }}$ edition.

Bauman, Z (1999): In Search of Politics. Cambridge. Polity Press.

Beck, Ul (1999): Risk society. Towards a new modernity. København: Hans Reitzels Forlag.

Beck, U (2002a): Words can be in silence. About terrorism and war. København: Hans Reitzels Forlag.

Beck, B (2002b): 'The Terrorist threat. World Risk Society Revisited', Theory, Culture \& Society, Volume 19 (4): 39-55.

Barry Buzan, B \& Wæver, O \& Wilde, J (1998): Security. A New Framework For Analysis. London: Lynne Rienner Publishers.

Canetti, E (1996): Crowds and Power. Princeton, New Jersey: Princeton University Press. 
Diken, B \& Carsten BL (2004): I Terrorens Skygge. Copenhagen: Samfundslitteratur.

Duyvesteyn, I (2010): "How New Is the New Terrorism", Studies in Conflict \& Terrorism, 27 (5): 439-454.

Foucault, M (2008) The Birth of Biopolitics. New York: Palgrave.

Gilliam, T (1985): Brazil. Embassy International Pictures.

Girard, R (1977) Violence and the Sacred. London: Continium.

Gürkaş, ET (2017) 'Border as “Zone of Indistinction”: The State of Exception and the Spectacle of Terror Along Turkey's Border With Syria.' Space and Culture, http://journals.sagepub.com/doi/abs/10.1177/1206331217741080

Hobbes, T (1990): Behemoth, or the Long Parliament. Chicago: University of Chicago Press.

Hobbes, T (1996). Leviathan. Cambridge: Cambridge University Press.

Kierkegaard, S (1981). The Concept Of Anxiety: A Simple Psychologically Orienting Deliberation on the Dogmatic Issue of Hereditary Sin (Kierkegaard's Writings, VIIII). Princeton: Princeton University Press.

Koolhaas, R, et al (1995) S,M,L,XL. New York: The Monacelli Press.

Laustsen, CB (2014): Terrorism. Aarhus: Aarhus University Press.

Laustsen, CB (2016): 'The anatomy of terrorism', Christian Daily Newspaper, 2/8, http://www.kristeligtdagblad.dk/kronik/terrorens-anatomi

Lotringer, S \& Virilio, P (1997) Pure War. Semiotex(e). New York: Columbia University Press.

Machiavelli, N (1999): The Prince. London: Penguin.

MacMaster, N (2004): "Making Torture Legal", New York Review of Books, 27/5.

Rancière, J. (2010) Dissensus. New York: Continuum.Robin, C (2004). Fear. The History of a Political Idea. Oxford: Oxford University Press.

Serres, M (2015) Rome. The First Book of Foundations. London: Bloomsbury.

Shields, R (2002) The Virtual. London: Routledge.

Sloterdijk, P (1988) Critique of Cynical Reason. London: Verso

Žižek, S (2003): "The (Mis) uses of Catastrophes ', Distinktion, Volume 6, pp. 137-144. 